\title{
A Case of Viral Hepatitis with Pleural Effusion
}

\author{
Motonobu Sugimoto, MD, Yasukiyo Sumino, MD, and Tohru Abei, MD
}

\begin{abstract}
A 27-year-old male was admitted to the Toho University Hospital with icterus and massive right pleural effusion containing $4.0 \mathrm{~g} / \mathrm{dl}$ of protein. The hepatocellular dysfunction and positive HBs antigen were revealed and he was diagnosed as typical acute viral hepatitis, type B. Evaluation for his pleural eff usion presented no evidence of pulmonary parenchymal disease, tuberculosis, or other systemic disorder. Since the effusion resolved with normalization of liver function tests, it is most likely that the eff usion was a complication of viral hepatitis. Cases with pleural effusion as the presenting sign of viral hepatitis are rare in the recent medical literature. A survey of publications disclosed the presence of this association in at least 11 patients, not including our own.
\end{abstract}

Key Words: Viral hepatitis, Liver biopsy, HBs antigen, Pleural effusion.

A 27-year-old businessman was admitted to the Toho University Hospital in September of 1976 for evaluation of icterus and pleural effusion. The patient had been well until 2 weeks prior to admission when he noticed general fatigue, anorexia, abdominal fullness and epigastric discomfort. He was entertained by a physician with the diagnosis of hepatitis. At that time, it was noted that serum glutamic oxaloacetic transaminase was 397 units, serum glutamic pyruvic transaminase was 501 units, while serum bilirubin level was normal. About 5 days after, dry cough, easy fatigability and nausea occured and dark urine was noticed. $\mathrm{He}$ had never been exposured to hepatotoxins including ethanol, and received neither surgical treatment nor blood transfusion. Physical examination revealed a jaundiced man in mild respiratory distress with a blood pressure of $110-70 \mathrm{mmHg}$, a regular pulse of 90 beast per minute, and a body temperature of $36.5^{\circ} \mathrm{C}$. The sclerae, palate and skin were icteric, but without rash. No lymphadenopathy was noted. There were dullness, decreased tactile fremitus and decreased breath sounds over the lower half of the right chest. The remainder of the chest was clear to auscultation. Cardiac examination revealed no rubs or murmurs. The liver was palpable $3 \mathrm{~cm}$ below the right costal margin with a tender, soft, sharp edge. The spleen was not palpable. There was no shifting dullness or fluid wave. Neurological and mental examination were negative.

Laboratory data showed hepatocellular injury and the following values: serum glutamic oxaloacetic transaminase, $214 \mathrm{RF}$ units; serum glutamic pyruvic transaminase, 300RF units; alkaline phosphatase, 142 international units; lactic dehydrogenase, 238 international units; icterus index, 55 ; total bilirubin, $5.8 \mathrm{mg} / \mathrm{dl}$; thymol turbidity test, 17.6SH units; zinc sulfate test, 11.4SH units; total protein, $6.3 \mathrm{~g} / \mathrm{dl}$; $\gamma$-globulin, 20.8\%; total cholesterol, $204 \mathrm{mg} /$

From the Second Department of Internal Medicine, School of Medicine, Toho University.

Received for publication May 22, 1978.

Reprint request to: Motonobu Sugimoto, The Second Department of Internal Medicine, School of Medicine Toho University 11-1, 6-chome Omori-nishi, Ota-ku, Tokyo 143, JAPAN. 
Table 1. Cases of pleural effusion associated with viral hepatitis (bibliographical)

\begin{tabular}{|l|c|c|c|}
\hline Authors & Year & $\begin{array}{c}\text { Number } \\
\text { of Cases }\end{array}$ & $\begin{array}{c}\text { Nature of Fluid } \\
\text { Protein } \\
(\mathrm{g} / \mathrm{dl})\end{array}$ \\
\hline Gross \& Gerding & 1971 & 1 & $\begin{array}{c}\text { exudative } \\
4.8\end{array}$ \\
\hline Katsi labros et al & 1972 & 4 & \\
\hline Owen E Shapiro & 1974 & 1 & exudative \\
\hline Forster et al & 1975 & 5 & $\begin{array}{c}\text { exudative } \\
3.0-4.0\end{array}$ \\
\hline ( Sugimoto et al ) & 1977 & 1 & $\begin{array}{c}\text { exudative } \\
4.0\end{array}$ \\
\hline
\end{tabular}

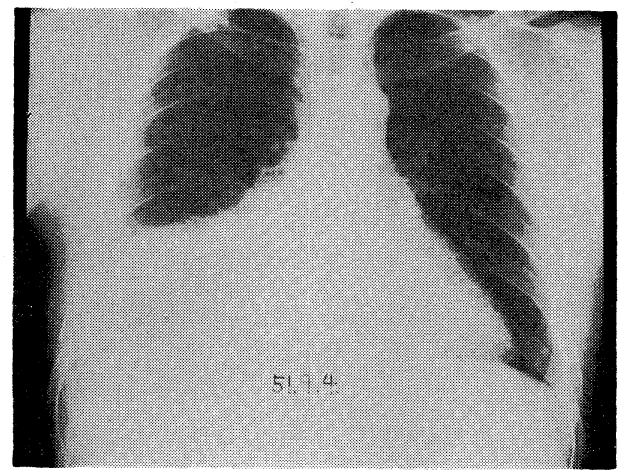

Fig. 1. Chest roentgenogram on admission. Massive right pleural effusion is evident.

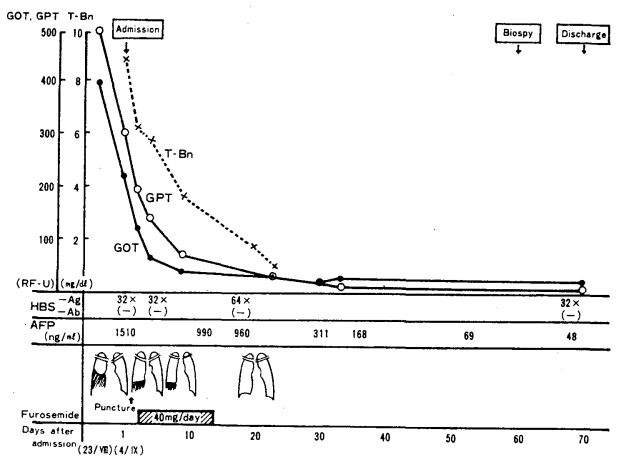

Fig. 2. Glinical course.

dl. HBs antigen was positive and $\alpha$-fetoprotein was also elevated.

Chest roentgenogram (Fig. 1) revealed a right pleural effusion. By thoracentesis $80 \mathrm{ml}$ of yellow fluid with a specific gravity of 1.032 and total protein of $4.0 \mathrm{~g} / \mathrm{dl}$ was

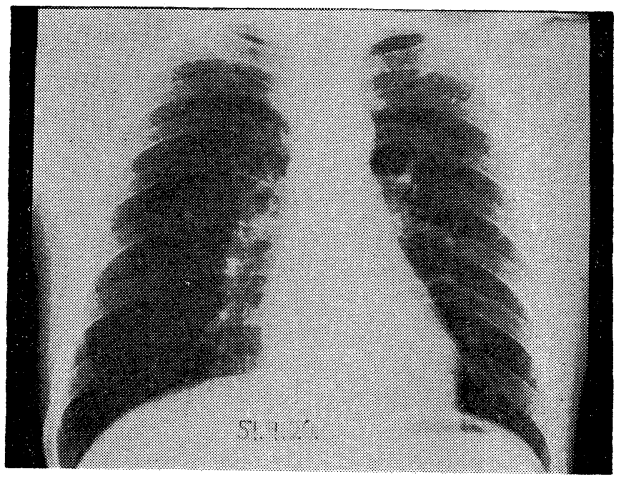

Fig. 3. Chest roentgenogram on the 20th day after admission. Pleural effusion completely disappeared.

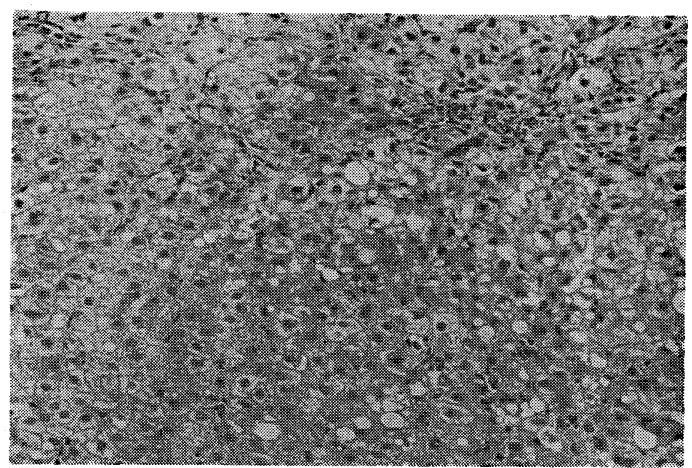

Fig. 4. Slight dissociation of hepatic cell cords with scattered necrotic lesions and diffuse fatty degeneration are seen. Binucleated cells are numerous. Edema and fibrosis with slight cell infiltration are seen in portal triad. (H. E. stain)

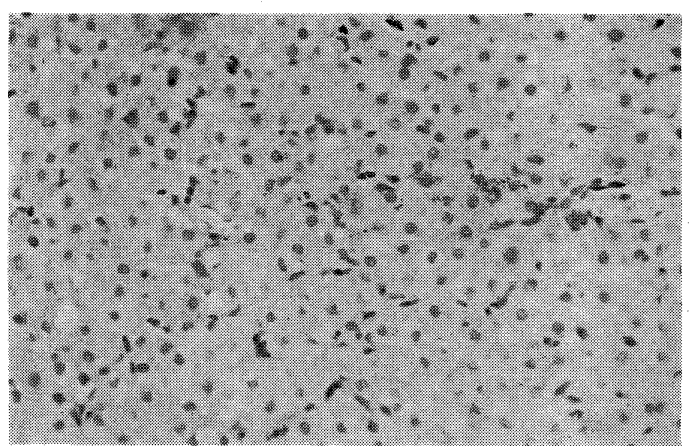

Fig. 5. Kupffer cell mobilization in the parenchyma with iron uptake strongly suggests viral hepatitis. (Perls' method for iron)

Jap J Med Vol 18, No 3 (July 1979) 


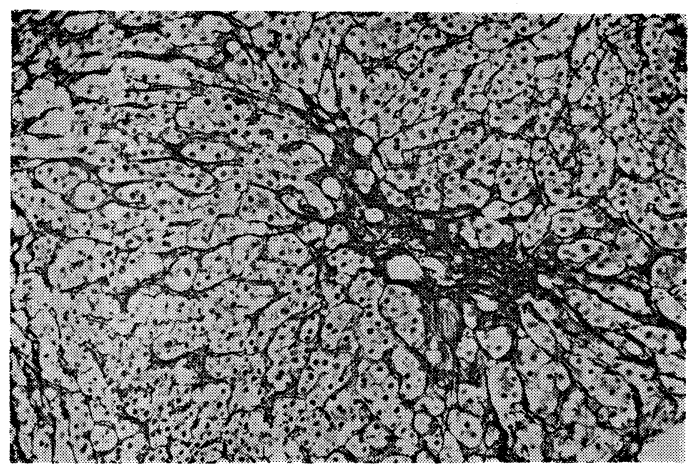

Fig. 6. Moderate collapse of lobular architecture is evident. (Reticulin stain)

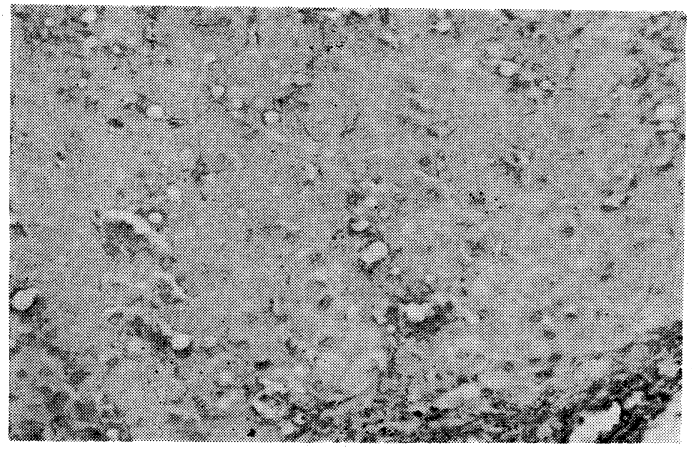

Fig. 7. HBs antigen is negative. (Shikata's method)

obtained. Microscopically, numerous reactive mesotherial cells and a few of matured lymphocytes and neutrophilic cells, but no malignant cell were seen. Gram stain and Ziehl-Neelsen stain were negative for bacteria, mycobacteria and fungi. Antibodies of viruses for Coxsackie A-9, B-1, Adeno and Cytomegalovirus were not elevated in the fluid.

Cultures of sputum and morning gastric aspirations were negative. Tuberculin skin test was positive, but chest films of leteral decubitus and postthoracentesis showed no evidence of parenchymal lung disease. Antibodies of viruses in serum for Influenza A, B, Parainfluenza 1, 11, Coxsackie A-9, B-1, B-3, Adeno, Mumps, Herpes simplex, Cytomegalovirus and R.S. virus were not elevated. Although $\mathrm{Pa}$ rainfluenza 111 and Rubella were slightly elevated, no changes were seen 3 weeks later. Electrocardiogram was within normal limits. An upper gastrointestinal X-ray series and barium enema study were normal. Liver scintiscanning showed no abnormalities.

Following the right thoracentesis, the patient was treated conservatively with bed rest and a high caloric diet. Furosemide $40 \mathrm{mg}$ per day was administrated for 10 days. During the first 10 days of hospitalization, the patient's condition was gradually improved and the liver size decreased accompanied by a return of the liver function tests toward normal (Fig. 2). Twenty days after the admission, pleural eflusion completely disappeared on the chest roentgenogram (Fig. 3), although diuretics had already been stopped. In this chest film no pulmonary parenchymal lesion was evident. About a month after the admission, values of transaminases and total bilirubin were completely normal and titer of $\alpha$-fetoprotein was decreased (Fig. 2 ). Liver biopsy was performed on the 58th day of hospitalization.

Microscopically (Fig. 4), a slight dissociation of the hepatic cell cords with minimal necrotic lesions and diffuse fatty degeneration were present in the lobulus. Binucleated cells were increased. Edema and fibrosis with a slight cell infiltration mainly of lymphocytes and some neutrophilic cells were seen in portal triad. A specimen stained by Perls' method (Fig. 5) showed a scattered iron uptake into Kupffer cells. On reticulin stain (Fig. 6), collapses of the lobular architecture was evident. A specimen stained by Shikata's method $^{1)}$ (Fig. 7) was negative for $\mathrm{HBs}$ antigen.

The patient was discharged on the 14 th day after the liver biopsy.

\section{DISCUSSION}

Although the route of transmission was not clear in this patient, his typical course and positive $\mathrm{HBs}$ antigen in the serum strongly suggested the diagnosis of acute viral hepatitis, type $B$, in spite of the presence of pleural exudation, which was 
the primary presenting sign. The histological finding was also consistent with the clinical diagnosis, with the exception of fatty degeneration, which is not the feature of viral hepatitis. Fatty degeneration may be associated with hepatitis, especially in a severe case, or in a patient overnurished during the convarescent period ${ }^{2}$. Moderately collapsed liver lobuli seen in the biopsy specimen taken on the 58th day of hospitalization, suggested that the hepatic damage in this patient might have been considerably severe.

Pleural effusion is well known as an occasional complication in hepatic diseases. In a series of 436 cases with pleural effusion, Leuallen and Carr ${ }^{3)}$ reported that $2 \%$ of the cases were due to liver cirrhosis. Johnston and $\mathrm{Loo}^{4)}$ reviewed 200 cases with cirrhosis and found the incidence of pleural effusion to be $6 \%$ (12 cases). In these patients, the pleural fluid was a transudate and the effusion was on the right in 8 , on the left in 2, and bilateral in 2. These authors, by injecting radioiodinated albumin into the pleural and peritoneal cavities and intravenously, suggested that the pleural fluid was derived from the peritoneal fluid. Lieberman et $\mathrm{al}^{5}$, in a study of 330 cases with cirrhosis and ascites, reported that the incidence of hydrothorax was $5.4 \%$ (18 cases).

In hepatitis, pleural effusion may be more usual than is commonly believed. In a prospective Italian study ${ }^{6}$, 70\% of 156 patients with hepatitis had at least a small pleural transudation ranging in quantity from 2 to $50 \mathrm{ml}$ and occasionally seen before the patients became noticeably jaundiced.

Exudative pleural effusions large enough for clinical detection have recently been observed as a complication of acute viral hepatitis ${ }^{7)-10)}$ (Table 1). The case of this association was first reported by Gross and Gerding $^{7)}$ in 1971. An 18-year-old girl with right-sided massive serous effusion containing $4.8 \mathrm{~g} \backslash \mathrm{dl}$ of total protein was presented. The effusion of this patient, initially suspected for tuberculosis, resolved accompanied by normalization of the liver function test. Adding to this report, effusions were seen in 4 cases out of 2500 patients with viral hepatitis, during a 10 year period in a Greek hospital ${ }^{8}$. However, in this description, the nature of effusions was not clarified.

Owen and Shapiro ${ }^{9)}$, in 1974, reported a case of 42-year-old male who had skin rash, anergy, exudative pleural effusion of the right chest and transient hematuria, presenting mildly depressed serum complement $\left(\mathrm{C}_{3}\right)$ as the initial sign of viral hepatitis. Forster et $\mathrm{al}^{10)}$, in 1975 , presented 3 cases of acute and 2 of chronic aggressive hepatitis associated with pleural effusion rich in protein (3-4/gdl). In 2 of these cases, positive test for $\mathrm{HBs}$ antigen in the fluid was demonstrated. These facts suggest a certain immunological factor or direct invasion of the virus as the cause of associated pleuritis. Further evidences are expected to know the real nature of this complication.

\section{REFERENCES}

1) Shikata $T$, Yoshizaki G, Okazaki K, et al : HBc-Ag and HBs-Ag in the hepatocytes. Acta Hepatologica 16: 201-208, 1975. (Japa nese)

2) Sherlock S: Virus hepatitis, in "Diseases of the liver and biliary system". 5th ed, p 305-339, Blackwell, Oxford, 1975.

3) Leuallen EC, Carr DT: Pleural effusion; A statistical study of 436 patients. New Eng J Med 252: 79-83, 1955.

4) Johnston RF, Loo RV : Hepatic hydrothorax ; Studies to determine the source of the fluid and report of thirteen cases. Ann Int Med 61 : 385-401, 1964.

5) Lieberman FL, Hidemura R, Peters RL, et al: Pathogenesis and treatment of hydrothorax complicating cirrhosis and ascites. Ann Int Med 64 : 341-351, 1966.

6) Sposito M, Petroni VA, Valeri L: Impotanza diagnostica dei piccoli versamenti pleurici nella virus epatite. Epatologia 12: 228-231, 1966.

7) Gross PA, Gerding DN: Pleural effusion associated with viral hepatitis. Gastroentero. $\log y 60$ : 898-902, 1971.

Jap J Med Vol 18, No 3 (July 1979) 
A Case of Viral Hepatitis with Pleural Effusion

8) Katsilabros L, Triandafillou G, Kontoyiannis $P$, et al: Pleural effusion and hepatitis. Gastroenterology 63 : 718, 1972.

9) Owen RL, Shapiro H: Pleural effusion, rash, and anergy in icteric hepatitis. New

Eng J Med 291: 963, 1974.

10) Forster W, Gueni B, Schmid M: Pleu raerguss; ein Symptom akuter und chronischer Hepatitis. Schweiz Med Wschr 105: 1714-1716, 1975. 